since, among other offices to which he had been called, he had been secretary of the Geological Society (when he organised the centenary celebrations), secretary and recorder of Section $\mathrm{C}$ of the British Association and prime mover in originating and running its Geological Photographs Committee.

In London, Watts was soon heavily engaged in administrative duties, both in the geological world and in the University, where he became chairman of the Board of Studies in Geology, dean of the Faculty of Science and senator. He planned the lay-out and equipment of a new department at the College and extended its activities by establishing a Sub-Department of Oil Technology shortly after his arrival, and after the First World War a Sub-Department of Mining Geology. With commendable foresight he insisted on the retention of the school of the fundamental science as a department of the Royal College of Science, while the other two departmentsapplied science appropriately found a home in the Royal School of Mines. Believing strongly in "Geology in the Service of Man" (the subject of one of his presidential addresses) he arranged for students of the City and Guilds College to attend a full course of lectures, laboratory work and field-surveying in geology for civil engineers, the first of its kind in Great Britain. Under his inspiration, research students steadily increased in numbers, coming from other universities in Britain, the Dominions and foreign countries.

Watts was wont to say that early in his London days he realized that he had to choose between being a teacher or a researcher. He never regretted his choice as time passed and he saw his old students occupying responsible posts, a score as professors, many as directors of geological surveys in various parts of the world, and even more as leading technologists in the business world, in oil, mining and other undertakings.

Among the public offices Watts filled were the presidential chair of Section C of the British Association (twice), the Geologists' Association (twice), the Geological Society, the Mineralogical Society and the British Association (Norwich, 1935). During 1917-23 he was secretary of the Conjoint Board of Scientific Societies-at the time when the world-embracing Catalogue of Scientific Periodicals was compiled.

Many other honours came to him. He was made an honorary fellow of Sidney Sussex College and of the Imperial College, hon. LL.D. of the Universities of St. Andrews and Edinburgh, fellow of the Royal Society (1904), Murchison Modallist (1915) and Wollaston Medallist (1927) of the Geological Society. $\mathrm{He}$ was an emeritus professor of the Imperial College and the University of London, an honorary fellow of the Royal Society of Edinburgh, a fellow of the Royal Society of Canada and an honorary member of many other learned societies.

Among the subjects he dealt with, in his characteristically vivid and witty style, wore informative reviews of palæogeography in the light of present-day crustal features, the potentialities of British coalfields, other economic aspects of the science, the history of geology and continental drift.

Such, in brief, is the record of a remarkable career. No man exercised more beneficent influence on the progress of British geology in his day, doubtless in no small measure by reason of his dominating personality, manifest humanity and great personal charm. Small wonder is it that his students felt an immense affection for him.

P. G. H. Boswell

\section{Mr. H. A. Hancock}

Coming straight from a Manchester school in 1916 to the newly formed Experimental Department of the Fine Spinners' and Doublers' Association, Ltd., Hancock presently became the writer's personal assistant. He had useful hands, and a remarkable freedom from subjective error; long dull serios of observations were in no way biased, and yet-the data at last obtained-he switched over to keenness in extracting every significant fact from them. In later years he similarly used statistical technique with exceptional discrimination. $\mathrm{He}$ became joint author of papers in cotton cell-wall structure, contributing several essential points. Although primarily a physicist, he acquired botanical interests which were of value later when he worked in closest liaison with cotton growers in a mill standing on a farm.

$\mathrm{He}$ was Lancashire, with a business sense, and also a diplomatist, so that he was the usual envoy to any distrustful mill manager. This diplomacy had full scope during his service in Egypt; but, like statistical technique or his skilled photography, it was only a tool for use in helping to do the job.

In the use of words his method was like a drawing by Phil May; nothing unessential was left in. Two pages of foolscap held his report on six weeks mission in the United States; nothing was omitted in its definite and important conclusions. It was his last writing before his death on July 23 at the age of forty-four.

In 1927 he moved to the Shirley Institute, Manchester, where he worked on the testing side, widening his experience of the cotton industry, taking a firstclass honours B.Sc. in physics and making a happy marriage with one of our former colleagues. Meanwhile, in Egypt it had been made practicable to start on the project of a spinning test mill. Hancock was not an obvious chief for it; he had never been a spinner, but the job was evidently going to be beyond all boundaries of procedent. So he arrived in 1934, finding only a climate-insulated building under construction for him to equip and staff. Scrupulously fair dealing served as a charm whereby skilled operatives were made out of raw material, and his infinite capacity for taking pains made the "S.T.M." incredibly efficient.

Results began to arrive fast and faster. Egypt had been promised a hundred and fifty tests a year, though privately we expected a thousand; after twelve years Hancock was producing a hundred and twenty a day with improved accuracy as routine, for weeks on end. Having shown mixtures to give an exact weighted-mean result he sampled all Egypt every year, with the collaboration of Alexandria's exporters, and thereby proved that smooth curves connected world-price and relative yarn-strengths. So the spinning-test became a direct valuation; after that we knew the market value of newly bred varieties years ahead of their public appearance. Matters of trade argument were swept up in the meshes of ordinary routine, a thousand spinnings or so at a time. Prediction of the all-important yarnstrength from the hair-properties was not quite complete, but the correlation coefficient reached 0.95 . He located the effects of 'grade' and analysed most of its causes. The detailed incidence of natural crossing in the field was measured by spinning.

Such things as these were all useful, but he struck a vein of fundamental resoarch by applying his technique to statistical genetics. Our unobtrusive 
handling of the crop by a seed-renewal system of pure lines, under spinning control, was adding to Egypt's wealth by more than fifteen million pounds yearly, but cracks were visible to us at Giza. Two pure-line varieties showed deterioration impending, which pure lines should not do. We knew our definition of 'purity' to be pragmatic, and no visible characters were at fault; nevertheless those yarns were getting weaker. Hancock used everything he possessed of physical and mental equipment in a complete demonstration and abolition of the trouble, laying down a simple 'nucleus-seed' control system whichIf the Egyptians continue to use it-has eliminated its recurrence. He first applied the spinning-test to all seed-lots of the high-quality cottons, arresting further decay; then he excavated through cubic metres of the plant-breeders' files from 1924 onward, until he could present the exact pedigree of every family ; this showed that an occasional use of openfertilized seed (against all orders) had introduced the unwanted genes. The strength of yarn was shown to integrate the effect of hundreds of genes, and the only available indicator of genic change was yarnstrength-which is the spinners' only requirement.

Hancock's last printed publication, towards the end of the War, was a trilogy of papers on the practical aspects of this theme. He had to re-write them completely, because the publishers disliked the style he had chosen to catch the spinners' interest. This, after five Egyptian war-time summers, was tiresome, for besides his proper work he had been helpful in many details of the war in the Middle East, and had directed a systematic examination of captured enemy textiles. A possibility of leave in 1945 had to be forgone, and by the winter he was involved in organising 'cotton missions' abroad, out of an exaggerated sense of loyalty to his Minister, himself taking the United States mission.

Meanwhile, he was offered the Bombay Technological Laboratory post, at threefold his pay in Egypt, and arranged to leave Giza after his American trip. Before he returned to Giza (his plane having been struck by lightning on the way) the Indian appointment had failed of confirmation, for political reasons, and he had to re-cast his plans. India's offer was renewed later, but by then he was on sickleave in England, with confidence lost, no longer able to cope with conditions. His keen interest in world affairs increased the depression induced by the frustrations of Egypt and India, so that the end was such tragedy as Hardy wrote.

W. Lawrence Balls

\section{NEWS and VIEWS}

\section{Agricultural Research Council : A New Institute of Animal Physiology}

The Agricultural Research Council, with the support of the Ministry of Agriculture and Fisheries and the Department of Agriculture for Scotland, has decided that in many directions progress towards the improvement of animal health and production is restricted by lack of knowledge of the fundamental physiology, normal and abnormal, of farm animals, and that to fill in some of the gaps in our knowledge a new Institute of Animal Physiology is needed. It has been decided that the Council should establish such an Institute, since the work which must be done needs the provision of buildings, land and large animals on a scale which would not be appropriate to a university department. Prof. I. de Burgh Daly, professor of physiology in the University of Edintourgh, has been appointed director, and will take office early in 1948. It is intended to appoint as Prof. Daly's senior colleagues a biochemist and a pathologist, so that the full range of problems bearing on the physiology of farm animals may be studied, including practical problems arising in the course of the handling and care of animals on the farm. A site for the new Institute has not yet been chosen, but preference will be given to one sufficiently near to a university to facilitate close contact between scientific workers in the Institute and those in University departments.

\section{Prof. I. de Burgh Daly, F.R.S.}

PROF. DALY has held the chair of physiology in the University of Edinburgh since 1933. He was educated at Rossall School, at the University of Cambridge, where he took first-class honours in Part I of the Natural Science Tripos and was Thurston Medallist of Caius College, and at St. Bartholomew's Hospital. In the First World War Prof. Daly was a fighter pilot in the Royal Naval Air Service. He was a member of the staff of the Department of Physiology, University College, London, during 1919-23, a Beit Memorial Fellow, and lecturer in experimental physiology in the University of Wales, Cardiff, in 1923, before being appointed professor of physiology in the University of Birmingham in 1927, where he worked until he was appointed to Edinburgh in 1933. During the Second World War, Prof. Daly carried out research on the physiology of high-altitude flying and on poison gases in Edinburgh during 1939-43. From 1943 until 1945 he was director of the Physiological Laboratory of the Medical Research Council at Lulworth, which was responsible for the investigation of the physiological factors determining the fighting efficiency of the crews in armoured fighting vehicles.

\section{Agriculture at the University of Reading}

THE autumn term at the University of Reading will witness two important changes in the professorial staff of the Faculty of Agriculture. The first is that Prof. H. A. D. Neville, who has occupied the chair of agricultural chemistry since 1919, and has been dean of the Faculty for almost as long a time, retires at the end of September. He is succeeded, as regards the chair, by Dr. Cyril Tyler, who has been lecturer in agricultural chemistry in the University. Prof. H. G. Sanders, professor of agriculture, will take over the duties of Dean of the Faculty.

Prof. Neville went to Reading with a training - undergraduate and post-graduate-under the late Prof. T. B. Wood in Cambridge and after service with the Forces in the First World War. At that time the University of Reading had not received its charter, the Faculty of Agriculture was scarcely on its feet, and the study of agricultural chemistry had barely begun. Prof. Neville's knowledge, administrative wisdom and drive as dean of the Faculty have been largely responsible for the unfaltering progress and development of the study of agriculture and its associated sciences, first in the University College and 